\title{
Pengujian Aplikasi Reservasi Lapangan Futsal dengan Metode Black Box Testing Menggunakan Teknik Boundary Value Analysis
}

\author{
Ni Putu Linda Santiari' ${ }^{1}$ I Gede Surya Rahayuda ${ }^{2}$ \\ ${ }^{1,2}$ Sistem Informasit, Institut Teknologi dan Bisnis STIKOM Bali, Jalan Raya Puputan No. 86 Renon, \\ Denpasar, Bali, 80234 \\ e-mail: ${ }^{1}$ linda_santiari@ stikom-bali.ac.id, ${ }^{2}$ surya_rahayuda@stikom-bali.ac.id
}

Submitted Date: July $25^{\text {th }}, 2020$

Revised Date: September $24^{\text {th }}, 2020$
Reviewed Date: September 22 $2^{\text {nd }}, 2020$

Accepted Date: September $30^{\text {th }}, 2020$

\begin{abstract}
The futsal court reservation application is an application that allows users and futsal court owners to more easily access without having to install additional applications that reduce the memory capacity on their smartphone. Before being used, this futsal field reservation application needs to be tested. Testing is a verification process for assessing the quality of a device software and see whether the software meets the expected processes and valid or not. The process that is not optimal can cause inequality of data to be stored in the database .. Testing is done by the Black Box Testing method. In black box testing there are several testing techniques, one of them is Boundary Value Analysis. The Boundary Value Analysis technique performs testing based on the maximum and minimum number of digits to produce valid and invalid values. The first stage carried out in this research is to identify the form functionality to be processed, ensuring the maximum and minimum number of characters entered. The results of testing the futsal field reservation application with the black box testing method with the Boundary Value Analysis technique are the quality of the software is in accordance with the function, and can be utilized properly by the user.
\end{abstract}

Keywords: Testing; Black Box Testing; Boundary Value Analysis

\begin{abstract}
Abstrak
Aplikasi reservasi lapangan futsal merupakan aplikasi yang memungkinkan pengguna dan pemilik lapangan futsal untuk lebih mudah mengakses tanpa harus install aplikasi tambahan yang mengurangi kapasitas memori pada smartphone mereka. Sebelum dipergunakan, aplikasi reservasi lapangan futsal ini perlu dilakukan pengujian. Pengujian adalah proses verifikasi untuk penilaian kualitas suatu perangkat lunak dan melihat apakah perangkat lunak memenuhi proses dan arahan yang diharapkan atau tidak. Proses yang tidak maksimal dapat menyebabkan ketidaksamaan data yang akan disimpan dalam database. Pengujian dilakukan dengan metode Black Box Testing. Dalam pengujian black box testing terdapat beberapa teknik pengujian salah satunya yaitu Boundary Value Analysis. Teknik Boundary Value Analysis melakukan pengujian berdasarkan jumlah digit maksimal dan minimal untuk menghasilkan nilai yang valid dan tidak valid. Tahap pertama yang dilakukan dalam penelitian ini yaitu dengan mengidenfitikasi fungsionalitas form yang akan diproses, memastikan banyaknya karakter maksimal dan minimal yang dimasukkan. Hasil dari pengujian aplikasi reservasi lapangan futsal dengan metode black box testing dengan teknik Boundary Value Analysis adalah kualitas dari perangkat lunak sudah sesuai dengan fungsi, serta dapat dimanfaatkan dengan baik oleh pengguna.
\end{abstract}

Kata kunci: Pengujian; Black Box Testing; Boundary Value Analysis

\section{Pendahuluan}

Saat ini banyak tempat futsal yang pemesanan atau booking dilakukan secara manual (Ratnasari, Hadi, \& Budiarto, 2018). Terlebih dahulu tim atau perwakilannya yang sudah memiliki nomor telepon dan ingin menyewa lapangan harus menelepon untuk bertanya ketersediaan lapangan pada hari dan jam yang ingin disewa sebelum melakukan pemesanan lapangan (Maimunah, Hariyansyah, \& Jihadi, 2017). Lain 
halnya dengan penyewa baru yang tidak mengetahui informasi kontak dari tempat futsal yang ada(Swastika \& Khasanah, 2017). Kekurangan dalam manajemen penyedia lapangan futsal juga dirasakan oleh pemilik tempat futsal, sebagai contoh tidak maksimalnya promosi yang dilakukan hanya dengan menyertakan plang nama membuat penyewaan lapangan menjadi tidak optimal dikarenakan tidak adanya jadwal yang pasti. Sering juga terjadi jadwal bentrok karena faktor human error atau kesalahan pemilik futsal yang lupa mencatat nama tim yang sudah melakukan pemesanan terlebih dahulu(Hidayat \& Prasetio, 2019).

Aplikasi Reservasi Lapangan Futsal merupakan aplikasi yang memungkinkan pengguna dan pemilik lapangan futsal untuk lebih mudah mengakses tanpa harus install aplikasi tambahan yang mengurangi kapasitas memori pada smartphone mereka. Website yang sudah terhosting dan terhubung nantinya akan menerima data-data dari pengguna yang melakukan reservasi lapangan futsal dan admin akan menerima serta mengkonfirmasi seluruh data yang telah disimpan di dalam database.

Untuk itu, sebelum aplikasi diterapkan pada penyewa lapangan dan pemilik lapangan futsal, terlebih dahulu dilakukan pengecekan secara menyeluruh oleh user, pengembang, dan penguji aplikasi. Pada saat pengujian terdapat kesalahan ketika proses menginputan data, sehingga data yang diharapkan tidak sesuai dengan database. Dengan ditemukan permasalahan, maka dapat disimpulkan bahwa masalah yang dihadapi adalah bagaimana agar data yang dimasukkan ke dalam aplikasi lebih akurat dan sesuai dengan tipe data maupun batas maksimal yang ditentukan(Yulistina, Nurmala, Supriawan, Juni, \& Saifudin, 2020). Sebagai contoh pada field no telepon, hanya bisa diisi karakter angka di mana batas maksimalnya adalah 12 digit. Dalam melakukan pengujian harus memilih teknik yang tepat, yaitu teknik yang dapat menemukan kesalahan yang belum terdeteksi sehingga dapat meningkatkan kualitas software (Hendri, Manurung, Ferian, Hanaatmoko, \& Yulianti, 2020). Metode yang dipergunakan untuk menguji kualitas aplikasi ini adalah metode Black Box dengan teknik Boundary Value Analysis. Metode Black Box dengan Teknik Boundary Value Analysis menggunakan data yang akan diuji berdasarkan nilai yang mendekati batas valid dan tidak valid(Jaya, 2018). Teknik Boundary Value Analysis dipergunakan dengan menentukan jumlah digit maksimal dan minimal yang ingin
diuji(Agushinta, Jatnika, \& Medyawati, 2019). Berdasarkan Teknik Boundary Value Analysis dalam pengujian ini, maka dapat dibuat beberapa tahapan pengujian perangkat lunak ini. Tahapan atau rencana dalam melakukan pengujian ini yaitu dengan menentukan jumlah digit maksimal dan minimal dengan menggunakan tabel test case(Tachiyama, Katayama, Kita, Yamaba, \& Okazaki, 2017). Dari tabel test case ini akan dipergunakan sebagai pengujian pada aplikasi reservasi lapangan futsal yang nantinya dapat dipergunakan sebagai bahan referensi.

\section{Metode Penelitian}

Penelitian ini dilakukan dengan merancang alur penelitian. Alur penelitian ini dibuat untuk mempermudah dalam proses penyusunan laporan. Gambar 1 merupakan tahapan yang dilakukan pada penelitian:

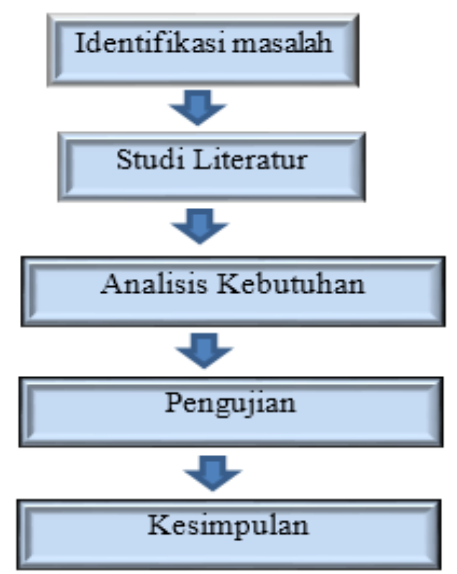

Gambar 1. Tahapan penelitian

Langkah awal yang dilakukan dalam penelitian ini yaitu mengecek aplikasi reservasi lapangan futsal menggunakan Line Bot. Kemudian dilanjutkan dengan studi literatur yang bertujuan untuk mengumpulkan data-data yang mendukung serta mempunyai kaitan dengan laporan tugas akhir ini yang bersifat teoritis dengan cara mengumpulkan literatur, jurnal, paper, dan bacaanbacaan yang ada kaitannya dengan judul penelitian. Erikutnya yaiu analisa kebutuhan yang dilakukan dengan menganalisa semua kebutuhan yang diperlukan untuk melakukan pengujian ini.. Analisa kebutuhan mencangkup kebutuan. Tahapan berikutnya yaitu melakukan proses pengujian. Metode pengujian yang dilakukan yaitu metode metode Black Box dengan Teknik Boundary Value Analysis. Black box testing, 
dilakukan tanpa pengetahuan detil struktur internal dari sistem atau komponen yang dites juga disebut sebagai behavioral testing, specification-based testing, input/output testing atau functional testing. Black box testing berfokus pada kebutuhan fungsional pada software, berdasarkan pada spesifikasi kebutuhan dari software(Leng et al., 2018). Black box testing bukan teknik alternatif daripada white box testing(Larrea, 2017). Lebih daripada itu, merupakan pendekatan pelengkap dalam mencakup error dengan kelas yang berbeda dari metode white box testing(Aliero, Ghani, Qureshi, \& Rohani, 2020).

Boundary value analysis adalah suatu teknik disain test cases yang berguna untuk melakukan pengujian terhadap nilai sekitar dari pusat domain masukan(Maheshwari, 2017). Teknik boundary value analysis merupakan komplemen dari teknik equivalence partitioning(Sutanto, Perbawa, \& Utomo, 2018). Setelah dilakukan pemilihan tiap elemen suatu kelas ekuivalensi (menggunakan equivalence partitioning), BVA melakukan pemilihan nilai batas-batas dari kelas untuk test cases. BVA tidak hanya berfokus pada kondisi masukan, BVA membuat test cases dari domain keluaran juga(Dobslaw, Neto, \& Feldt, 2020). Test cases dilakukan untuk menguji nilai-nilai di kedua sisi dari batasan. Sebagai contoh pada gambar 2., partisi "Ujian" memberikan nilai batasan tes untuk menguji nilai "Ujian" pada -1, 0, 1, 74, 75, dan 76

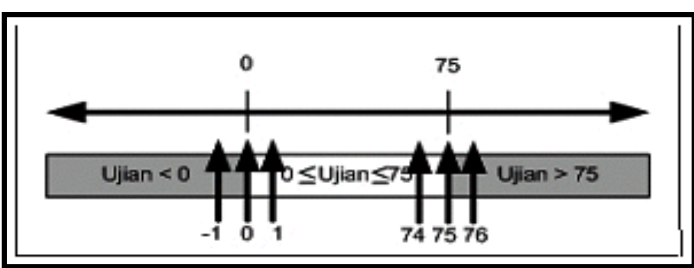

Gambar 2. Contoh boundary value analysis

Tahapan terakhir menginterpretsikan hasil yang didapat dan menarik kesimpulan dari hasil yang didapat.

\section{Hasil dan Pembahasan}

\subsection{Analisa Kebutuhan}

Dalam aplikasi ada terdapat beberapa form diantaranya form pencarian reservasi lapangan, form sewa lapangan, form konfirmasi pembayaran, form login, dan form tambah lapangan. Dalam penelitian ini, pengujian dilakukan pada form form pendaftaran lapangan. Form pendaftaran lapangan dapat dilihat pada Gambar 3. Dalam form pendaftaran lapangan, admin dapat menambah informasi dan data lapangan baru.

\section{Pendaftaran Lapangan}

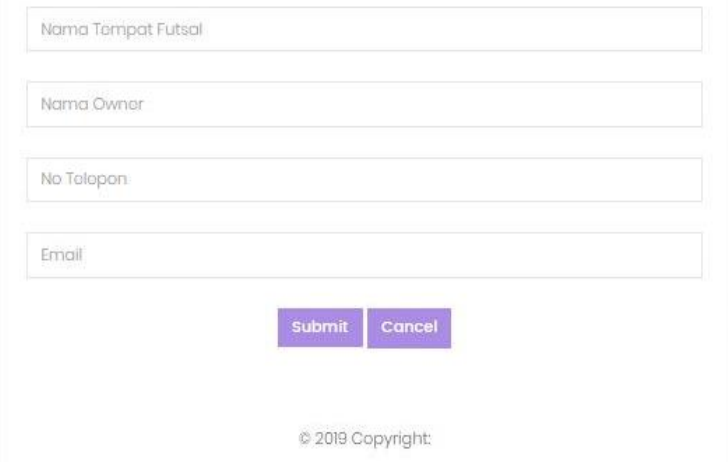

Gambar 3. Form Pendaftaran Lapangan

Admin juga dapat mengedit data lapangan yang telah ditambahkan sebelumnya. Adapun data yang dimasukkan yaitu nama lapangan dengan maksimal panjang data 25 huruf, angka dan spasi. Nama owner dengan maksimal panjang data 30 huruf dan spasi. No telepon dengan maksimal panjang data 12 angka dan spasi dan email dengan maksimal panjang data 25 karakter, huruf dan angka.. Dalam boundary value analysis perlu adanya test case, untuk field nama lapangan test case dapat dilihat pada Tabel 1 . Test case field nama owner dapat dilihat pada Tabel 2. Test case field no telepon dapat dilihat pada Tabel 3. Test case field email dapat dilihat pada Tabel 4.

Tabel 1. Test Case Field Nama Lapangan

\begin{tabular}{|l|l|l|}
\hline ID & Skenario & Hasil yang diharapkan \\
\hline Test1 & $\begin{array}{l}\text { Memasukkan nama lapangan "Metro } \\
\text { Futsal” selanjutnya yang harus dilakukan } \\
\text { adalah klik Tambah }\end{array}$ & $\begin{array}{l}\text { Data berhasil ditambah dalam } \\
\text { database. }\end{array}$ \\
\hline Test2 & $\begin{array}{l}\text { Memasukkan nama lapangan "Planet88 } \\
\text { Futsal !!" selanjutnya yang harus dilakukan } \\
\text { adalah klik Tambah }\end{array}$ & $\begin{array}{l}\text { Karakter "!!" ditolak dan tidak dapat } \\
\text { dimasukkan untuk ditambahkan dalam } \\
\text { database }\end{array}$ \\
\hline
\end{tabular}




\begin{tabular}{|l|l|l|}
\hline Test3 & $\begin{array}{l}\text { Memasukkan nama lapangan "Dewata Bali } \\
\text { Gatot Subroto Futsal" selanjutnya yang } \\
\text { harus dilakukan adalah klik Tambah }\end{array}$ & $\begin{array}{l}\text { Karakter melebihi batas input dan } \\
\text { tidak dapat dimasukkan untuk } \\
\text { ditambahkan dalam database }\end{array}$ \\
\hline Test4 & $\begin{array}{l}\text { Memasukkan nama lapangan “ " } \\
\text { selanjutnya yang harus dilakukan adalah } \\
\text { klik Tambah }\end{array}$ & $\begin{array}{l}\text { Karakter kosong dan tidak dapat } \\
\text { dimasukkan untuk ditambahkan dalam } \\
\text { database }\end{array}$ \\
\hline
\end{tabular}

Tabel 2. Test Case Field Nama Owner

\begin{tabular}{|l|l|l|}
\hline ID & Skenario & Hasil yang diharapkan \\
\hline Test5 & $\begin{array}{l}\text { Memasukkan nama owner“I Putu Agus } \\
\text { Sanjaya" selanjutnya yang harus dilakukan } \\
\text { adalah } \\
\text { klik Tambah }\end{array}$ & $\begin{array}{l}\text { Data berhasil ditambah dalam } \\
\text { database. }\end{array}$ \\
\hline Test6 & $\begin{array}{l}\text { Memasukkan nama owner "Tompel_XI" } \\
\text { selanjutnya yang harus dilakukan adalah } \\
\text { klik Tambah }\end{array}$ & $\begin{array}{l}\text { Karakter “_“ ditolak dan tidak dapat } \\
\text { dimasukkan untuk ditambahkan dalam } \\
\text { database }\end{array}$ \\
\hline Test7 & $\begin{array}{l}\text { Memasukkan nama owner "I Komang } \\
\text { Dalem Widnyana Arta Wijaya” selanjutnya } \\
\text { yang harus dilakukan adalah } \\
\text { klik Tambah }\end{array}$ & $\begin{array}{l}\text { Karakter melebihi batas input dan tidak } \\
\text { dapat dimasukkan untuk ditambahkan } \\
\text { dalam database }\end{array}$ \\
\hline Test8 & $\begin{array}{l}\text { Memasukkan nama owner " " selanjutnya } \\
\text { yang harus dilakukan adalah } \\
\text { klik Tambah }\end{array}$ & $\begin{array}{l}\text { Karakter kosong dan tidak dapat } \\
\text { dimasukkan untuk ditambahkan dalam } \\
\text { database }\end{array}$ \\
\hline
\end{tabular}

Tabel 3. Test Case Field No Telepon

\begin{tabular}{|l|l|l|}
\hline ID & Skenario & Hasil yang diharapkan \\
\hline Test9 & $\begin{array}{l}\text { Memasukkan no telepon“08123456789” } \\
\text { selanjutnya yang harus dilakukan adalah } \\
\text { klik Tambah }\end{array}$ & $\begin{array}{l}\text { Data berhasil ditambah dalam } \\
\text { database. }\end{array}$ \\
\hline Test10 & $\begin{array}{l}\text { Memasukkan no telepon “-08134567892” } \\
\text { selanjutnya yang harus dilakukan adalah } \\
\text { klik Tambah }\end{array}$ & $\begin{array}{l}\text { Karakter “_c ditolak dan tidak dapat } \\
\text { dimasukkan untuk ditambahkan dalam } \\
\text { database }\end{array}$ \\
\hline Test11 & $\begin{array}{l}\text { Memasukkan no telepon "0814567A892” } \\
\text { selanjutnya yang harus dilakukan adalah } \\
\text { klik Tambah }\end{array}$ & $\begin{array}{l}\text { Huruf "A” tidak dapat dimasukkan } \\
\text { untuk ditambahkan dalam databse }\end{array}$ \\
\hline Test12 & $\begin{array}{l}\text { Memasukkan no telepon " selanjutnya } \\
\text { kang harus dilakukan adalah }\end{array}$ & $\begin{array}{l}\text { Karakter kosong dan tidak dapat } \\
\text { dimasukkan untuk ditambahkan dalam } \\
\text { database }\end{array}$ \\
\hline
\end{tabular}

Tabel 4. Test Case Field Email

\begin{tabular}{|l|l|l|}
\hline ID & Skenario & Hasil yang diharapkan \\
\hline Test13 & $\begin{array}{l}\text { Memasukkan } \\
\text { email“metro_futsal@gmail.com” } \\
\text { selanjutnya yang harus dilakukan adalah } \\
\text { klik Tambah }\end{array}$ & Data berhasil ditambah dalam database. \\
\hline Test14 & $\begin{array}{l}\text { Memasukkan email "metro } \\
\text { futsal@gmail.com” selanjutnya yang harus } \\
\text { dilakukan adalah } \\
\text { klik Tambah }\end{array}$ & $\begin{array}{l}\text { Pemberian spasi ditolak dan tidak dapat } \\
\text { dimasukkan untuk ditambahkan dalam } \\
\text { database }\end{array}$ \\
\hline
\end{tabular}




\begin{tabular}{|l|l|lr|}
\hline Test15 & $\begin{array}{l}\text { Memasukkan no telepon " " selanjutnya } \\
\text { yang harus dilakukan adalah } \\
\text { klik Tambah }\end{array}$ & $\begin{array}{l}\text { Karakter kosong dan tidak dapat } \\
\text { dimasukkan untuk ditambahkan dalam } \\
\text { database }\end{array}$ \\
\hline
\end{tabular}

\subsection{Hasil Pengujian}

Dari pembuatan tabel test case yang telah dibuat, selanjutnya dilaksanakan pengujian. Pengujian dilakukan metode Black Box dengan
Teknik Boundary Value Analysis berdasarkan test case yang telah dibuat. Hasil pengujian yang dilakukan ditunjukkan pada Tabel 5.

Tabel 5. Hasil Pengujian

\begin{tabular}{|c|c|c|c|c|}
\hline ID & Skenario & $\begin{array}{l}\text { Hasil yang } \\
\text { diharapkan }\end{array}$ & Hasil Pengujian & Kesimpulan \\
\hline Test1 & $\begin{array}{l}\text { Memasukkan nama lapangan } \\
\text { "Metro Futsal" selanjutnya yang } \\
\text { harus dilakukan adalah klik } \\
\text { Tambah }\end{array}$ & $\begin{array}{lr}\text { Data } & \text { nama } \\
\text { lapangan } & \text { "Metro } \\
\text { Futsal" berhasil di } \\
\text { tambah r dalam } \\
\text { database. }\end{array}$ & $\begin{array}{l}\text { Muncul pesan "Data } \\
\text { berhasil ditambahkan" } \\
\text { dan data nama } \\
\text { lapangan "Metro } \\
\text { Futsal" berhasil di } \\
\text { tambahkan dalam } \\
\text { database }\end{array}$ & Sesuai \\
\hline Test2 & $\begin{array}{l}\text { Memasukkan nama lapangan } \\
\text { "Planet88 Futsal !!" selanjutnya } \\
\text { yang harus dilakukan adalah klik } \\
\text { Tambah }\end{array}$ & $\begin{array}{l}\text { Karakter "!!" } \\
\text { ditolak dan tidak } \\
\text { dapat dimasukkan } \\
\text { untuk } \\
\text { ditambahkan } \\
\text { dalam database }\end{array}$ & $\begin{array}{l}\text { Muncul pesan "Data } \\
\text { tidak bisa di } \\
\text { tambahkan" dan data } \\
\text { tidak bisa ditambahkan } \\
\text { dalam database }\end{array}$ & Sesuai \\
\hline Test3 & $\begin{array}{l}\text { Memasukkan nama lapangan } \\
\text { "Dewata Bali Gatot Subroto } \\
\text { Futsal" selanjutnya yang harus } \\
\text { dilakukan adalah klik Tambah }\end{array}$ & $\begin{array}{l}\text { Karakter melebihi } \\
\text { batas input dan } \\
\text { tidak dapat } \\
\text { dimasukkan untuk } \\
\text { ditambahkan } \\
\text { dalam database }\end{array}$ & $\begin{array}{l}\text { Muncul pesan "Data } \\
\text { tidak bisa di } \\
\text { tambahkan" dan data } \\
\text { tidak bisa ditambahkan } \\
\text { dalam database }\end{array}$ & Sesuai \\
\hline Test4 & $\begin{array}{l}\text { Memasukkan nama lapangan “" } \\
\text { selanjutnya yang harus dilakukan } \\
\text { adalah klik Tambah }\end{array}$ & $\begin{array}{l}\text { Karakter kosong } \\
\text { dan tidak dapat } \\
\text { dimasukkan untuk } \\
\text { ditambahkan } \\
\text { dalam database }\end{array}$ & $\begin{array}{l}\text { Muncul pesan "Data } \\
\text { tidak boleh kosong" } \\
\text { dan data tidak bisa } \\
\text { ditambahkan dalam } \\
\text { database }\end{array}$ & Sesuai \\
\hline Test5 & $\begin{array}{l}\text { Memasukkan nama owner"I Putu } \\
\text { Agus Sanjaya" selanjutnya yang } \\
\text { harus dilakukan adalah klik } \\
\text { Tambah }\end{array}$ & $\begin{array}{lr}\text { Data } & \text { berhasil } \\
\text { ditambah } & \text { dalam } \\
\text { database. } & \end{array}$ & $\begin{array}{l}\text { Muncul pesan "Data } \\
\text { berhasil ditambahkan" } \\
\text { dan data berhasil } \\
\text { ditambahkan dalam } \\
\text { database }\end{array}$ & Sesuai \\
\hline Test6 & $\begin{array}{l}\text { Memasukkan nama owner } \\
\text { "Tompel_XI" selanjutnya yang } \\
\text { harus dilakukan adalah klik } \\
\text { Tambah }\end{array}$ & $\begin{array}{l}\text { Karakter “-“" } \\
\text { ditolak dan tidak } \\
\text { dapat dimasukkan } \\
\text { untuk } \\
\text { ditambahkan } \\
\text { dalam database }\end{array}$ & $\begin{array}{l}\text { Muncul pesan "Data } \\
\text { tidak bisa } \\
\text { ditambahkan" dan data } \\
\text { tidak bisa ditambahkan } \\
\text { dalam database }\end{array}$ & Sesuai \\
\hline Test7 & $\begin{array}{l}\text { Memasukkan nama owner "I } \\
\text { Komang Dalem Widnyana Arta } \\
\text { Wijaya" selanjutnya yang harus }\end{array}$ & $\begin{array}{l}\text { Karakter melebihi } \\
\text { batas input dan } \\
\text { tidak dapat } \\
\text { dimasukkan untuk }\end{array}$ & $\begin{array}{l}\begin{array}{l}\text { Muncul pesan "Data } \\
\text { bisa }\end{array} \\
\text { tidak } \\
\text { ditambahkan" dan data }\end{array}$ & Sesuai \\
\hline
\end{tabular}




\begin{tabular}{|c|c|c|c|c|}
\hline & $\begin{array}{l}\text { dilakukan } \\
\text { klik Tambah }\end{array}$ & $\begin{array}{l}\text { ditambahkan } \\
\text { dalam database }\end{array}$ & $\begin{array}{l}\text { tidak bisa ditambahkan } \\
\text { dalam database }\end{array}$ & \\
\hline Test8 & $\begin{array}{l}\text { Memasukkan nama owner " " } \\
\text { selanjutnya yang harus dilakukan } \\
\text { adalah } \\
\text { klik Tambah }\end{array}$ & $\begin{array}{l}\text { Karakter kosong } \\
\text { dan tidak dapat } \\
\text { dimasukkan untuk } \\
\text { ditambahkan } \\
\text { dalam database }\end{array}$ & $\begin{array}{l}\text { Muncul pesan "Data } \\
\text { tidak boleh kosong" } \\
\text { dan data tidak bisa } \\
\text { ditambahkan dalam } \\
\text { database }\end{array}$ & Sesuai \\
\hline Test9 & $\begin{array}{l}\text { Memasukkan } \\
\text { telepon“08123456789" } \\
\text { selanjutnya yang harus dilakukan } \\
\text { adalah } \\
\text { klik Tambah }\end{array}$ & $\begin{array}{l}\text { Data berhasil di } \\
\text { tambah dalam } \\
\text { database. }\end{array}$ & $\begin{array}{l}\text { Muncul pesan "Data } \\
\text { berhasil ditambahkan" } \\
\text { dan data berhasil di } \\
\text { tambahkan dalam } \\
\text { database }\end{array}$ & Sesuai \\
\hline Test10 & $\begin{array}{l}\text { Memasukkan no telepon “- } \\
\text { 08134567892" selanjutnya yang } \\
\text { harus dilakukan adalah } \\
\text { klik Tambah }\end{array}$ & $\begin{array}{l}\text { Karakter “_.“ } \\
\text { ditolak dan tidak } \\
\text { dapat dimasukkan } \\
\text { untuk } \\
\text { ditambahkan } \\
\text { dalam database }\end{array}$ & $\begin{array}{l}\text { Muncul pesan "Data } \\
\text { tidak bisa di } \\
\text { tambahkan" dan data } \\
\text { tidak bisa ditambahkan } \\
\text { dalam database }\end{array}$ & Sesuai \\
\hline Test11 & $\begin{array}{l}\text { Memasukkan no telepon } \\
\text { "0814567A892" } \\
\text { yang harus dilakukan adalah } \\
\text { klik Tambah }\end{array}$ & $\begin{array}{l}\text { Huruf "A" tidak } \\
\text { dapat dimasukkan } \\
\text { untuk } \\
\text { ditambahkan } \\
\text { dalam databse }\end{array}$ & $\begin{array}{l}\text { Muncul pesan "Data } \\
\text { tidak bisa di } \\
\text { tambahkan" dan data } \\
\text { tidak bisa ditambahkan } \\
\text { dalam database }\end{array}$ & Sesuai \\
\hline Test12 & $\begin{array}{l}\text { Memasukkan no telepon “" " } \\
\text { selanjutnya yang harus dilakukan } \\
\text { adalah } \\
\text { klik Tambah }\end{array}$ & $\begin{array}{l}\text { Karakter kosong } \\
\text { dan tidak dapat } \\
\text { dimasukkan untuk } \\
\text { ditambahkan } \\
\text { dalam database }\end{array}$ & $\begin{array}{l}\text { Muncul pesan "Data } \\
\text { tidak boleh kosong" } \\
\text { dan data tidak bisa } \\
\text { ditambahkan dalam } \\
\text { database }\end{array}$ & Sesuai \\
\hline Test13 & $\begin{array}{l}\text { Memasukkan } \\
\text { email“metro_futsal@gmail.com" } \\
\text { selanjutnya yang harus dilakukan } \\
\text { adalah } \\
\text { klik Tambah }\end{array}$ & $\begin{array}{l}\text { Data berhasil di } \\
\text { tambah dalam } \\
\text { database. }\end{array}$ & $\begin{array}{l}\text { Muncul pesan "Data } \\
\text { berhasil ditambahkan" } \\
\text { dan data berhasil di } \\
\text { tambahkan dalam } \\
\text { database }\end{array}$ & Sesuai \\
\hline Test14 & $\begin{array}{l}\text { Memasukkan email "metro } \\
\text { futsal@gmail.com" selanjutnya } \\
\text { yang harus dilakukan adalah } \\
\text { klik Tambah }\end{array}$ & $\begin{array}{l}\text { Pemberian spasi } \\
\text { ditolak dan tidak } \\
\text { dapat dimasukkan } \\
\text { untuk } \\
\text { ditambahkan } \\
\text { dalam database }\end{array}$ & $\begin{array}{l}\text { Muncul pesan "Data } \\
\text { tidak bisa di } \\
\text { tambahkan" dan data } \\
\text { tidak bisa ditambahkan } \\
\text { dalam database }\end{array}$ & Sesuai \\
\hline Test15 & $\begin{array}{l}\text { Memasukkan no telepon “" " } \\
\text { selanjutnya yang harus dilakukan } \\
\text { adalah } \\
\text { klik Tambah }\end{array}$ & $\begin{array}{l}\text { Karakter kosong } \\
\text { dan tidak dapat } \\
\text { dimasukkan untuk } \\
\text { ditambahkan } \\
\text { dalam database }\end{array}$ & $\begin{array}{l}\text { Muncul pesan "Data } \\
\text { tidak boleh kosong" } \\
\text { dan data tidak bisa } \\
\text { ditambahkan dalam } \\
\text { database }\end{array}$ & Sesuai \\
\hline
\end{tabular}

\section{Kesimpulan}

Pengujian yang dilakukan pada aplikasi reservasi lapangan futsal dengan menggunakan metode black box testing dengan teknik Teknik Boundary Value Analysis dapat membantu proses pembuatan case pengujian dan uji kualitas. Hasil pengujian untuk form tambah lapangan berhasil $100 \%$. Pengujian yang dilakukan dengan metode Black Box Testing dengan teknik Boundary Value Analysis yang relevan untuk 
diterapkan pada aplikasi reservasi lapangan futsal dengan menentukan jumlah limit minimum serta limit maksimum dari struktur data yang telah dirancang.

\section{Saran}

Pengujian pada Aplikasi Reservasi Lapangan Futsal ini diharapkan dapat menjadi sumber referensi untuk pengujian selanjutnya. Penulis menyarankan agar penelitian selanjutnya saat pengujian tidak hanya menggunakan satu metode pengujian, sehingga hasil yang didapatkan bisa lebih valid lagi. Penggunaan beberapa metode pengujian akan memberikan hasil dan perbandingan yang lebih baik untuk meningkatkan kualitas dari perangkat lunak yang diuji.

\section{Referensi}

Agushinta, R. D., Jatnika, I., \& Medyawati, H. (2019). Boundary Value Analysis Testing on Augmented Reality of Indonesian Fruit Recognition at Mekarsari Tourist Park using Cloud Method on Android Mobile Devices. Journal of Physics: Conference Series, 1196(1), 12060. IOP Publishing.

Aliero, M. S., Ghani, I., Qureshi, K. N., \& Rohani, M. F. (2020). An algorithm for detecting SQL injection vulnerability using black-box testing. Journal of Ambient Intelligence and Humanized Computing, 11(1), 249-266.

Dobslaw, F., Neto, F. G. de O., \& Feldt, R. (2020). Boundary Value Exploration for Software Analysis. ArXiv Preprint ArXiv:2001.06652.

Hendri, H., Manurung, J. W. H., Ferian, R. A., Hanaatmoko, W. F., \& Yulianti, Y. (2020). Pengujian Black Box pada Aplikasi Sistem Informasi Pengelolaan Masjid Menggunakan Teknik Equivalence Partitions. Jurnal Teknologi Sistem Informasi Dan Aplikasi, 3(2), 107-113.

Hidayat, A., \& Prasetio, F. (2019). Sistem informasi sewa lapang futsal di ciawi kabupaten tasikmalaya. Jutekin (Jurnal Teknik Informatika), $7(2)$.

Jaya, T. S. (2018). Pengujian Aplikasi dengan Metode Blackbox Testing Boundary Value Analysis (Studi Kasus: Kantor Digital Politeknik Negeri
Lampung). Jurnal Informatika: Jurnal Pengembangan IT, 3(1), 45-48.

Larrea, M. L. (2017). Black-box testing technique for information visualization. Sequencing constraints with low-level interactions. Journal of Computer Science \& Technology, 17-23.

Leng, X., Zhou, B., Deng, X., Davis, L., Sutton, M. A., Shazly, T., \& Lessner, S. M. (2018). Determination of Viscoelastic Properties of human Carotid Atherosclerotic Plaque by Inverse Boundary Value Analysis. IOP Conference Series. Materials Science and Engineering, 381-389. NIH Public Access.

Maheshwari, M. (2017). Boundary Value Analysis for Input Variables with Functional Dependency.

Maimunah, M., Hariyansyah, H., \& Jihadi, G. (2017). Rancang bangun Sistem Aplikasi Penyewaan Lapangan Futsal Berbasis Web. SEMNASTEKNOMEDIA ONLINE, 5(1), 4-7.

Ratnasari, D., Hadi, H. F., \& Budiarto, J. (2018). Rancang Bangun Aplikasi Penyewaan Lapangan Futsal Berbasis Android. JUTI: Jurnal Ilmiah Teknologi Informasi, 16(2), 144-157.

Sutanto, Y., Perbawa, D. S., \& Utomo, A. (2018). PENGUJIAN Aplikasi Website Menggunakan Black Box Testing Boundary Value Analysis (Studi Kasus: Aplikasi website praktekdokter). Jurnal Sainstech, 5(2), 52-57.

Swastika, R. H., \& Khasanah, F. N. (2017). Sistem Informasi Reservasi Lapangan Futsal Pada Futsal Corner Menggunakan Metode Waterfall. Jurnal Mahasiswa Bina Insani, 1(2), 251-266.

Tachiyama, H., Katayama, T., Kita, Y., Yamaba, H., \& Okazaki, N. (2017). Prototype of test cases automatic generation tool BWDM based on boundary value analysis with VDM++. International Conference on Artificial Life and Robotics, 275-278.

Yulistina, S. R., Nurmala, T., Supriawan, R. M. A. T., Juni, S. H. I., \& Saifudin, A. (2020). Penerapan Teknik Boundary Value Analysis untuk Pengujian Aplikasi Penjualan Menggunakan Metode Black Box Testing. Jurnal Informatika Universitas Pamulang, 5(2), 129-135. 